\title{
On the university
}

Edward W. Saïd ${ }^{4}$

Mr. President, Senator Hatfield, members of the AUC Board of Trustees, members of the AUC faculty and administrative staff, members of the graduating class, distinguished guests, parents, relatives and friends, ladies and gentlemen:

I don't mind admitting to you as a sign of my almost biblical age, that I grew up in Cairo fifty years ago during the 1940s, and that the American University in Cairo was the first university I had anything to do with. Two of my Jerusalem cousins were students here, my father was a close friend of John Badeau, AUC's president then, later John Kennedy's Ambassador to Egypt, and, finally, Ewart Hall was Cairo's main concert hall, where the rudiments of my musical education were formed. I was also gradually aware of AUC's great national counterparts, Cairo University, and al-Azhar, each of them, like AUC, doing something very valuable for generations of Egyptian, Arab, and Muslim students. I am also proud to say that in 1994 my son Wadie perfected his quite extraordinary command of Arabic at CASA here, a major achievement for a New York City kid who, as a matter of solidarity with his Arab origin, made himself remarkably fluent in the language and culture of his heritage, at a time when both were objects of cultural hostility in the United States, the land of his birth and upbringing. I am honored and pleased to be here today, first, as an Arab Palestinian and a child of Egypt's immense and unparalleled cultural history, and, second, as an American. The combination of these two different strains in AUC, and of course in you, the class of 1999, the last class of the century, is both highly challenging and even enriching, but it is also quite problematic. Anyone

4 This article first appeared as: SAIID, Edward W. On the University. Alif: Journal of Comparative Poetics, n. 25, p. 26-36, 2005. 
who knows both societies knows what kinds of differences exist between American and Egyptian societies, so I won't dwell here on what is obvious. What is worth noting is that in institutions like AUC, and its counterpart $A U B$, the idea of a secular liberal education, pioneered in the nineteenth and twentieth centuries by the great colleges of the United States, was implanted with very positive results in mostly Islamic, Arab, and, in terms of sheer longevity, extremely old societies in the process of renewing and liberating themselves after long periods of outside domination.

Whatever the results of this bold mixture, they are neither simple nor entirely predictable. Each of you, teachers and students alike, must have your own assessment based on your years of interacting with dizzyingly different ideas, different personal experiences, expectations, frustrations, and fulfillments, but I can't imagine that anyone of you would say that the results were anything less than interesting, rich, and, yes, unsettling. The main thing, though, is that this collective, mixed experience of yours has taken place, and for future students and teachers will continue to take place, in a very special location, namely, a university. As someone who has spent all his adult life working in, and for, the university, let me assure you, as one of my own teachers once said it, it's certainly a lot more fun than working. Many of you, graduates with real jobs in the real world, will certainly discover that.

But that isn't my main point, which is that in every known society - from the ancient Near East, the Arab world to China, India, Greece, and elsewhere - the academy, as Plato called it, was a protected, almost utopian place. Only there could collective learning and the development of knowledge occur and, as in recent years we have discovered, it could occur only if academic freedom from non-academic authority was somehow guaranteed and could prevail. It is an extraordinary thing to discover via George Makdisi's remarkable book The Rise of Humanism in Classical Islam and the Christian West that the origins of the modern system of knowledge that we call humanism did not originate, as Jakob Burckhardt and many others believed it did, in Italy during the fifteenth- and sixteenthcentury Renaissance, but, rather, in the Arab colleges, madrasas, mosques, and courts of Iraq, Sicily, Egypt, Andalusia, from the eighth century on. And in those places were formed the traditions and the curricula of legal, theological, as well as secular, learning - the so-called studia adabiya - 
from which European humanists, like Pico della Mirandola, Ficino, Aretino, and Thomas Moore, derived many of their ideas, not only about learning itself, but also about the environment of learning, where disputation, dissent, and argument were the order of the day.

For those of us who are of Arab origin, and who in the modern period have gotten used to the notion that Europe and the West gave rise to modes of study, notions of academic discipline, and the whole idea of what in Arabic we call ijtihad, or the central role of individual effort in study and interpretation, it is salutary indeed to realize that our ArabIslamic culture contributed substantially to what later was to become the whole system of education, which today we call modern, liberal, and Western. I have very little patience with ethnocentrism of the kind trumpeted by Samuel Huntington, and others like him who claim that all ideas of democracy, freedom, and enlightenment are Western ideas, since the facts of history are, as we now know with reference to education, very mixed, very various, very much a matter of the contribution made by all humankind, all peoples, all cultures. There isn't a single source for anything: All peoples share in the making of history, all peoples make history. So let us agree, then, that whether we look to the time of Ibn 'Abbad or Ibn 'Arabi, or that of John Dewey in the twentieth century, we will find serious thinkers suggesting more or less the same thing, that the place of education is a special province within the society, a place where freedom of inquiry and thought occur and are protected, and where - it must be said - the social and political context plays an important role, by defining the limits and expectations of the learning process. The American University in Cairo is in Cairo, therefore, not in New York or London. That is obvious. Cairo is a specific environment with its own history, laws, language, and norms: Not to take account of all of that is plain wrong.

Yet, the status of university or school, as well as what goes along with them intellectually and socially, is special, is different from other sites in society, like the government bureaucracy, the workplace, or the home. The fact is, I believe, that all societies today assign a special privilege to the academy that, whether it exempts it from intercourse with the everyday world or whether it involves it directly in that world, says that unique conditions do, indeed ought to, prevail in it. To say that someone is 
educated, or an educator, is to say something having to do with the mind, with intellectual and moral values, with a particular process of inquiry, discussion, and exchange, none of which is as regularly encountered outside as they are inside the academy. The idea is that academies form the mind of the young, prepare them for life, just as - to look at things from the point of view of the teacher - to teach is to be engaged in a vocation or calling having principally to do, not with financial gain, but with the unending search for truth.

These are very high and important matters, and for those of us who have made education our life. they testify to the genuine aura surrounding the academic and intellectual enterprise. There is something hallowed and consecrated about the academy: There is a sense of violated sanctity, experienced by us when the university or school is subjected to crude political pressures. Yet, I believe, to be convinced of these genuinely powerful truths is not entirely to be freed of the circumstances - some would call them encumbrances - that impinge on education today, influence our thinking about it, shape our efforts in the academy. The point I want to make is that, as we consider these situational or contextual matters, the search for academic freedom, to which such occasions as this are so manifestly dedicated, becomes more important, more urgent, more requiring of careful and reflective analysis. So whereas it is universally true that contemporary societies treat the academy with seriousness and respect, each community of academics, intellectuals, and students must wrestle with the problem of what academic freedom in that society at that time actually is, and should be.

The best definition of a university that I know is by John Henry Cardinal Newman, who in 1854 came from England to Ireland to establish what has since become University College, Dublin. Here is what he said on the occasion:

A university has this object and this mission; it contemplates neither moral impression nor mechanical production; it professes to exercise the mind neither in art nor in duty; its function is intellectual culture; here it may leave its scholars, and it has done its work when it has done as much as this. It educates the intellect to reason well in all matters, to reach out towards truth and to grasp it. 
Perhaps you young graduates don't feel that you had this experience, or perhaps you feel that, now that you have finished your course of study, you need no longer be concerned with the university, except as an alumnus. That would be a mistake. You are not only graduates and former students, you are citizens, and citizenship requires resolute attention to what is most important about the life of your society. And surely there can be nothing more important in the long run of Egypt's life than education, and the life of the mind, especially here in our part of the world, where, alas, we lag behind in democracy, the freedoms of expression, opinion, and the press, and full participation in societies so long dominated by national security concerns, and not the intellectual and civic health of the people. So the freedom of the university is a lifelong concern, and it requires your sustained support and concern.

But to return to Newman. Note the care with which he selects his words for what actions take place in the pursuit of knowledge: words like exercise, educates, reach out, and grasp. In none of these words is there anything to suggest coercion, or direct utility, or immediate advantage or dominance. "Knowledge," Newman says in another place, is "something intellectual, something which grasps what it perceives through the senses; something which takes a view of things; which sees more than the senses convey; which reasons upon what it sees, and while it sees; which invests it with an idea." Then he adds: "not to know the relative disposition of things is the state of slaves or children; to have mapped out the universe is the boast, or at least the ambition, of philosophy," which Newman defines as the highest state of knowledge.

These are incomparably eloquent statements, and they can only be a little deflated when we remind ourselves that Newman was speaking to, and about, English men, not women, and then also about the education of young Catholics, not of Egyptians or Arabs. Nonetheless, the profound truth in what Newman says is, I believe, designed to undercut any partial, or somehow narrow, view of education whose aim might seem only to re-affirm one particularly attractive and dominant identity, religion, and authority, that which is the resident power or authority of the moment. Perhaps, like many of his Victorian contemporaries, Newman was arguing earnestly for a type of education that placed the highest premium on English, European, or Christian values in knowledge. But sometimes, even 
though we may mean to say something, another thought at odds with what we say insinuates itself into our rhetoric, and in effect criticizes it, delivers a different and less assertive idea than on the surface we might have intended. This happens when we read Newman. Suddenly we realize that, although he is obviously extolling what is an overridingly Western conception of the world, with little explicit allowance made for what is African, or Arab, or Latin American, or Indian, we realize that he says that education should map out the universe, thus letting slip the notion that even an English or Western identity wasn't enough, wasn't at bottom, or at best, what education and freedom were all about, which are about "the universe."

Certainly, it is difficult to find in Newman anything like a license, either for blinkered specialization or for gentlemanly aestheticism. What he expects of the academy is, he says, "the power of viewing many things at once as one whole, of referring them severally to their true place in the universal system, of understanding their respective values, and determining their mutual dependence." This synthetic wholeness has a special relevance to the fraught political situations of conflict, the unresolved tension, and social as well as moral disparities that are constitutive to the world of today's academy. He proposes a large and generous view of human diversity. To link the practice of education and, by extension, of freedom in the academy directly to the settling of political scores, or to an equally unmodulated reflection of real national and religious conflict, is neither to pursue knowledge nor, in the end, to educate ourselves and our students, which is an everlasting effort at understanding. But what happens when we take Newman's prescriptions about viewing many things as one whole, or referring them to their true place in the universal system, and we transpose these notions to today's world of embattled national identities, cultural conflicts, and power relations? Is there any possibility of bridging the gap between the ivory tower of contemplative rationality, ostensibly advocated by Newman, and our own urgent need as Arabs for self-realization and self-assertion with its background in a history of repression and denial? Can the university survive as a real university if its governance and teaching mission become the objects of scrutiny and direct interference, not of its teachers, but of powers outside the university?

I think not. I will go further and say that it is precisely the role of the contemporary academy to keep open the gap between itself and society, 
since society itself is too directly ruled by politics to serve so general and so finally intellectual and moral a role as the university plainly must. We must first, I think, accept that nationalism or religion resurgent, or even nationalism and religion militant, whether it is the nationalism of the victim or of the victor, such a nationalism has its limits. Nationalism and religion are the philosophy of identity made into a collectively organized passion. For those of us just emerging from marginality and persecution, our traditions constitute a necessary thing: A long deferred and denied identity needs to come out into the open and take its place among other human identities. But that is only the first step. To make all, or even most of, education subservient to this goal is to limit human horizons, without either intellectual or, I would argue, political warrant. To assume that the ends of education are best advanced by focusing principally on our own separateness, or what accords with our own ethnic identity, culture, and traditions ironically places us where, as inferior or lesser races, we had been placed by nineteenth-century racial theory, unable to share in the general riches of human culture. To say that women should read mainly an approved women's literature, Muslims should study and perfect only approved Muslim techniques of understanding and interpretation, that Arabs should return to a set of acceptable works for all knowledge and wisdom, that they should in a university read only what is considered safe and orthodox, is in fact to keep us back, to prevent us from participating in the march of humanity. There is room for all at the rendezvous of victory, said Aime Cesaire; no race has a monopoly on beauty or intelligence.

A single over-mastering identity guided by a religious or secular authority outside the academy at the core of the academic enterprise, whether that identity be Western, African, Islamic, Arab, or Asian, is a confinement, a deprivation. The world we live in is made up of numerous identities, numerous ideas, lives, philosophies interacting, sometimes harmoniously, sometimes antithetically. Not to deal with that whole which is in fact a contemporary version of the whole referred to by Newman as a true enlargement of mind - is not to have academic freedom. We cannot make our claim as seekers after justice, if we advocate knowledge only of and about ourselves, knowledge only that is approved by a team of referees who decide what can and cannot be read. Who then will referee the referees? Now, one of the innovations of an American University in 
Egypt is precisely that it encourages its students to experience not only their culture and traditions, but another set as well. This, I believe, is deeply enriching, perhaps unsettling, and the very opposite of homogenizing learning into only one approved form. But it is being challenged, and it must resist attempts at book banning or prohibiting ideas.

Our model for academic freedom should therefore be the migrant or traveler: For if, in the real world outside the academy, we must needs be ourselves and only ourselves, inside the academy, like this one, we should be able to discover and travel among other selves, other identities, other varieties of the human adventure. But, most essentially, in this joint discovery of self and other, it is the role of the academy to transform what might be conflict, or contest, or assertion into reconciliation, mutuality, recognition, creative interaction. But, rather than viewing the search for knowledge in the academy as the search for coercion and control over others, we should regard knowledge as something for which risks must be taken, and we should think of academic freedom as an invitation to explore knowledge, in the hope of understanding, and perhaps even assuming, more than one kind. We must always view the academy as a place to voyage in, owning none of it, but at home everywhere in it. There can be no forbidden knowledge if the modem university is to maintain its place, its mission, its power to educate.

An altogether different challenge to the concept of academic freedom is found in national universities in much of the contemporary Arab world. I speak here, generally, of most of the large public universities in countries all through the area. Most of these countries are, in fact, run by secular governments. What is important to understand, however, is that, with few exceptions, Arab universities are not only nationalist universities, but are also political institutions, for perfectly understandable reasons. In Palestine, Bir Zeit and al-Najah, for instance, have resisted Israeli occupation and preserved Palestinian identity admirably. Elsewhere, the Arab world which had been dominated, either by Ottoman or by European colonialism, became independent after World War II. National independence, for countries like Egypt and Syria, meant that young people at last could be educated fully in the traditions, histories, languages, and cultures of their own particular Arab countries. In my own case, for instance, I was educated entirely in British colonial schools, in Palestine 
and Egypt, where everything was focused on the history of British society, its literature, and values. Much the same was true in the main British and French colonies, such as India and Algeria, where it was assumed that native elites would be taught the rudiments of intellectual culture, in idioms and methods designed, in effect, to keep those native elites basically subservient to colonial rule, the superiority of European learning, and so forth. Until I was about sixteen, I knew a great deal more about the eighteenth-century enclosure system in England than I did about how the Islamic waqf operated in my own part of the world, and to me - irony of ironies - colonial proconsuls, like Cromer and Kitchener, were more familiar to me than Haroun al-Rashid or Khalid ibn al-Walid.

So that when independence was achieved, as a result of anticolonial struggles, one of the first things to be changed was education. I recall, for instance, that after the Revolution of 1952 in Egypt, a great deal of emphasis was placed on the Arabization of the curriculum, of intellectual norms, of values to be inculcated in schools and universities. The same was true of Algeria after 1962, where an entire generation of Muslims were, for the first time, entitled and enjoined to study Arabic, which had been forbidden except as a language in mosques, while Algeria was considered and ruled as a department of France. It is important to understand, therefore, the justified passion that went into reclaiming the educational territory, for so long dominated by foreign rulers in the Arab world, and it is equally important to understand the tremendous spiritual wound felt by many of us, because of the sustained presence in our midst of domineering foreigners who taught us to respect distant norms and values more than our own. Our culture was felt to be of a lower grade, perhaps even congenitally inferior, and something to be ashamed of.

Now it would be both wrong, and even absurd, to suggest that a national education based on Arabic norms is, and of itself, either trivial or impoverished. Of course not. Yet, it is also true to say that in the newly independent countries of the Arab world, the national universities were often re-conceived, I believe, as (rightly or wrongly) extensions of the newly established national security state. Once again, it is clear that all societies accord a remarkable privilege to the university and school, as crucibles for the shaping of national identity. This is true everywhere, at sometimes too high a price. In the US there was a great deal of pressure 
on universities to benefit the defense department, especially during the Cold War and the Vietnam War.

Yet, all too often in the Arab world, true education has been shortcircuited, so to speak. Whereas in the past young Arabs fell prey to the intervention of foreign ideas and norms, now they were to be remade in the image of the ruling party, which, given the Cold War, and the Arab-Israeli struggle, became also the party of national security, and, in some countries, the only party. Thus adding to the vastly increased pressure on universities to open their doors to everyone in the new society - an extremely admirable policy pioneered in Egypt - universities also became the proving ground for earnest patriots. This was also true during the McCarthy period in the US, when anyone suspected of left-wing ideas was persecuted. Professorial appointments were, as they are in many places in the world today, the equivalent of civil service appointments. Yet, alas, political conformity, rather than intellectual excellence, was often made to serve as a criterion for promotion and appointment, with the general result that timidity, a studious lack of imagination, careful conservatism came to rule intellectual practice. This is a danger everywhere - in the US, Europe, the Third World, etc. Often the atmosphere of the university has changed from freedom to accommodation, from brilliance and daring to caution and fear, from the advancement of knowledge to self-preservation.

Not only did many brilliant and gifted people leave the Arab world in a massive brain drain, but I would say that the whole notion of academic freedom underwent a significant downgrading during the past three decades. It became possible for one to be free in the university only if one completely avoided anything that might attract unwelcome attention or suspicion. I do not want to make of this occasion a long, anguished recital of how badly demoralized and discouraged a place the Arab world, in most of its contemporary aspects, has become, but I do think it is important to link its depressed situation with the lack of democratic rights, the absence of a free press, and of an atmosphere bereft of well-being and confidence in the society. No one can say that these things are not connected to each other, because they so obviously are. Political repression has never been good for academic freedom, and, perhaps more importantly, it has been disastrous for academic and intellectual excellence when such things as book banning and censorship are practiced. My assessment, as I said, is 
that too high a price has been paid where political or religious passions, and an ideology of conformity, are allowed to dominate, and perhaps even to swallow up, civil institutions, such as the university. To make the practice of intellectual discourse dependent upon conformity to a pre-determined political or religious ideology is to nullify intellect altogether. It comes, finally, to two images for inhabiting the academic and cultural space provided by the university. On the one hand, authority is there in order to reign and hold sway. Here, in such a conception of academic space, the academic professional and the public authority is the sultan and potentate. In that form, teaching teaches students not to question, but to follow authority, not to be skeptical - which is to continue searching - but to cling to dogma. The other model is considerably more mobile, more playful, although no less serious. The image of traveler depends not on power, but on motion, on a willingness to go into different worlds, use different idioms, understand a variety of disguises, masks, rhetorics, and be free to do so, and to be critical, to think for oneself. Travelers must suspend the claim of customary routine, in order to live in new rhythms and rituals. Most of all, and most unlike the sultan who must guard only one place and defend its frontiers, the traveler crosses over, traverses territory, abandons fixed positions, all the time. To do this with dedication and love, as well as a realistic sense of the terrain, is, I believe, academic freedom at its highest, since one of its main features is that you can leave authority and dogma to the sultan. Academic freedom is risk and danger. It means allowing oneself a few years where the conventions of society are suspended, so that the search for knowledge can go on for the love of knowledge alone. To be a life-long member in the academic world, as you new graduates and your teachers are, is therefore to enter a ceaseless quest for principles and knowledge, liberation, and finally justice. 